\title{
Differential gene expression between Zucker Fatty rats and Zucker Diabetic Fatty rats: a potential role for the immediate-early gene Egr-1 in regulation of beta cell proliferation
}

\author{
Kay E Garnett ${ }^{1,2}$, Philip Chapman ${ }^{2}$, Julie A Chambers ${ }^{2}$, Ian D Waddell ${ }^{2}$ and \\ David S W Boam ${ }^{1}$
}

${ }^{1}$ School of Biological Sciences, University of Manchester, Michael Smith Building, Oxford Road, Manchester M13 9PT, UK

${ }^{2}$ AstraZeneca, Mereside, Alderley Park, Macclesfield, Cheshire SK10 4TG, UK

(Requests for offprints should be addressed to D Boam; Email: d.boam@man.ac.uk)

\begin{abstract}
The $\beta$-cell failure that characterises type 2 diabetes is likely to involve altered expression of many genes. We aimed to identify global changes in gene expression underlying $\beta$-cell dysfunction in pre-diabetic Zucker Diabetic Fatty rat islets, followed by functional studies to verify our findings. Gene expression profiles in islets from 6-week-old Zucker Diabetic Fatty rats and Zucker Fatty rat controls were analysed using Affymetrix microarrays. Totally 977 genes were found to be differentially regulated, comprising large groups of membrane and structural proteins, kinases, channels, receptors, transporters, growth factors and transcription factors. We are particularly interested in transcription factors, which can have profound effects on cellular function. Thus a subset of those with no role yet defined in the $\beta$-cell was selected for further study namely the immediate-early gene Egr-1, PAG608, rCGR19 and mSin3b. Tissue specificity of these factors varied but interestingly Egr-1 expression was highly enriched in the pancreatic islet. To determine a possible role of Egr-1 in the $\beta$-cell, Egr-1 expression in INS-1 cells was silenced using RNA interference (RNAi). Glucose-stimulated insulin secretion in these cells was then measured using ELISA and cell proliferation was measured by $\left[{ }^{3} \mathrm{H}\right]$ thymidine incorporation. Small interfering RNA (siRNA)-mediated silencing of the Egr-1 gene inhibited its induction by glucose but had no observable effect on glucose-stimulated insulin secretion. However, Egr-1 gene silencing did inhibit proliferation of INS-1 cells in a glucose-independent manner. Our studies have revealed a role for Egr-1 and suggest that reduced Egr-1 gene expression may contribute to decreased $\beta$-cell proliferation and the consequent $\beta$-cell failure observed in the later stages of type 2 diabetes.
\end{abstract}

Journal of Molecular Endocrinology (2005) 35, 13-25

\section{Introduction}

Type 2 diabetes (T2D) is characterised by the inability of the pancreatic $\beta$-cell to secrete adequate quantities of insulin in order to compensate for hyperglycaemia arising from peripheral insulin resistance and increased hepatic glucose output. There is currently much controversy surrounding the aetiology of the disease. However, it is apparent that insulin resistance alone is insufficient to cause diabetes, as suggested by studies on animal models of T2D (Griffen et al. 2001) and gene ablation studies in mice (Tamemoto et al. 1994, Terauchi et al. 1997) and that a progression to overt diabetes also requires $\beta$-cell failure (Polonsky et al. 1996). The exact causes of pancreatic $\beta$-cell failure remain unknown. Chronic exposure to high glucose and elevated free fatty acid levels, observed in humans and in animal models of T2D is detrimental to $\beta$-cell function, resulting in blunted glucose-induced insulin secretion and increased levels of apoptosis (Pick et al. 1998, Prentki et al. 2002). There remains the underlying genetic predisposition to T2D, which is less well characterised. Study of the monogenic forms of maturity-onset diabetes of the young (MODY) has revealed that genetically predetermined $\beta$-cell dysfunction can arise via different pathways, such as deranged mitochondrial function, reduced $\beta$-cell mass and decreased insulin synthesis (Wang et al. 2002). The genetic predisposition to non-MODY T2D is probably due to more subtle variations in gene expression caused by multiple polymorphisms, which probably combine and interact to alter the response of $\beta$-cells to environmental stress, as well as innately affecting their capacity for neogenesis and regeneration. Both humans and animal studies have indicated that decreased neogenesis and differentiation coupled with increased apoptosis may play a major role in the failure to increase the $\beta$-cell mass required to compensate for peripheral insulin resistance (Pick et al. 
1998, Jonas et al. 1999, Finegood et al. 2001, Weir et al. 2001). Recent studies, however, indicate that proliferation rather than neogenesis plays a more prominent role in maintenance of beta cell mass in adult islets than neogenesis from stem cell populations (Brun et al. 2004, Dor et al. 2004).

In order to study the molecular basis of $\beta$-cell dysfunction in T2D, we used the Zucker Diabetic Fatty (ZDF) rat, a well characterised animal model of T2D, and compared it with the Zucker Fatty rat $(f a / f a)$ control. The Zucker Fatty rat carries a spontaneous mutation in the leptin receptor gene ( $f a$ ) (Phillips et al. 1996), causing obesity and insulin resistance. The ZDF rat was derived by selective inbreeding of hyperglycaemic Zucker Fatty rats and is thus as insulin resistant and obese as the Zucker Fatty rat; however it goes on to develop overt diabetes around 10 weeks of age (Etgen \& Oldham. 2000). Comparison of the ZDF and Zucker Fatty rat specifically allows the study of progression to diabetes, separate from the effect of insulin resistance and obesity. Previous studies have investigated specific gene-function defects in ZDF islets (Seufert et al. 1998), as well as an inherited defect in the binding of as yet unidentified proteins to the insulin gene promoter (Griffen et al. 2001). However, since $\beta$-cell failure is likely to involve a change in the expression of a large number of genes, we used microarrays, which allow analysis of global gene expression, to study the transcriptional changes that occur in pre-diabetic ZDF islets in comparison with Zucker-Fatty islets.

We focussed our subsequent studies on a subset of differentially regulated transcription factors because of their known profound and pleiotrophic effects on $\beta$-cell function. We performed further studies on the immediate-early gene, Egr-1, which was down-regulated in ZDF islets, because other studies suggest it plays a role in the regulation of cell proliferation, differentiation and survival (Perez-Castillo et al. 1993, Dinkel et al. 1998, Thiel \& Cibelli 2002, Pignatelli et al. 2003) and it is induced by several insulin secretagogues in a calciumdependent manner (Josefsen et al. 1999, Bernal-Mizrachi et al. 2001). We show here that Egr-1 expression is strikingly enriched in islets and that its small interfering RNA (siRNA)-mediated silencing inhibits $\beta$-cell proliferation. Taken together, these findings suggest a significant role for Egr-1 in $\beta$-cell proliferation.

\section{Materials and methods}

\section{Animals}

Zucker Fatty rats $(f a / f a)$ were obtained from the animal breeding unit at AstraZeneca Pharmaceuticals (Alderley Park, Cheshire, UK). Zucker Diabetic Fatty (ZDF) $(f a / f a)$ rats were obtained from Genetic Models Inc. (P.O. Box 68737, Indianapolis, IN, USA). Animals were maintained on a $12 \mathrm{~h}$ light:12 h darkness schedule with standard laboratory diet and water available ad libitum and were culled at approximately $0900 \mathrm{~h}$. Animal procedures were undertaken by license from the British Home Office in compliance with the Animal Scientific Procedures Act 1986. The diabetic animals used in this study exhibit the same phenotype as described previously (Lee et al. 1994).

\section{Islet isolation}

Pancreatic islets were isolated from six 6-week-old male $\mathrm{ZDF}$ and ten 6-week-old male Zucker rats by collagenase digestion as described by Montague \& Taylor 1968. Briefly, pancreata were inflated with ice-cold Gey and Gey physiological buffer using a syringe. The distended pancreas was rapidly chopped into fine, uniform pieces using sharp scissors, then rinsed with ice-cold Gey and Gey buffer. The pancreas was then digested with 6-8 $\mathrm{mg}$ collagenase (Sigma, C-9407 type XI) by shaking vigorously in a $37{ }^{\circ} \mathrm{C}$ water bath for $\sim 5 \mathrm{~min}$, or until the mixture has no lumps. This was then centrifuged at $400 \boldsymbol{g}$ for $1 \mathrm{~min}$ followed by another wash with physiological buffer. The islets were then picked by hand using a Gilson pipette and a dissecting microscope. To remove as much exocrine tissue contamination as possible, the islet suspension was diluted further in buffer and the islets picked a second time.

\section{Sample preparation and microarray analysis}

Total RNA was extracted from rat islets using TRizol reagent according to the manufacturer's instructions (Invitrogen) and purified by passing through a column from the Qiagen RNeasy Total RNA isolation kit (Qiagen). ZDF and Zucker RNA samples were generated from pooled islet preparations, in order to decrease the eventual natural variation in gene expression changes. Total RNA $(5 \mu \mathrm{g})$ was converted to double-stranded cDNA with the Superscript Choice System (Life Technologies), using an HPLC purified oligo-dT primer containing a T7 RNA polymerase promoter $\left(5^{\prime}\right.$-ggccagtgaattgtaatacgactcactatagggaggcgg$\left.(\mathrm{dT})_{24}-3^{\prime}\right)$. In vitro transcription (IVT) was performed on this purified template using Bioarray High Yield RNA Transcript Labelling Reagents (Enzo Diagnostics, Farmingdale, NY, USA) according to the manufacturer's instructions, in which biotinylated CTP and UTP were incorporated. These labelled cRNAs (targets) were generated in duplicate from the pooled ZDF and Zucker RNA samples due to previous studies (data not published), which revealed that most false positives are generated in the target preparation step. Targets were then fragmented and hybridised to RG-U34 arrays (Affymetrix, Santa Clara, CA, USA) as described 
Table 1 Primer and probe oligonucleotide sequences

Forward primer

Gene
BTE
Egr-1
Fe65L2
GKLF
HPRT
mSin3b
PAG608
Ring finger binding protein
rCGR19 aacgccactcacgggactag agagccaagtccttctagtcagtagaa ccctagggttctgtagcctctca tgtaacatttttatgcagacagtctgt cgagccgaccggttctg aatgggtcgtgcgagatga acttgtcacttggccattgaga acctccagtagctgcacaagg cctgcctgtgcgacagct
Reverse primer

tggctatacacccatttatcagctaa gggcagggacgctaagtga caacgaacttggtcataaatacagagta acacatttgttctgcttaaaggcatac cataacctggttcatcactaatcac gcgagcgcttcttgtgttc tgtagccccagaacatagagactg tcttgtccaatcaccctatgtc gcaaaggattcctgcacaaact
Probe (labelled 5'FAM, 3'TAMRA)

acgctgcaagagcattgggctctgt
cccgttggccaccagccct
tcctgccatccctgatcccttgc
atgcactgtggttcagatgtgcaataatttg
cagcaccttgtggtcctcacctgg
cagcgcacagaagaatgaggagaagagtc
tctgagcaggccatcgggcagt
ccctgcttggctcatggagggac
caagcagtgtcccatgtgccgc

previously (Der et al. 1998). Probe arrays were scanned using a GeneChip array scanner (Affymetrix).

\section{Data and statistical analysis of Affymetrix microarray data}

Quantitative analysis of differential expression was performed using Microarray suite $4 \cdot 0$ (Affymetrix). Microsoft Excel software was also used for data analysis. Normalisation of scanned images was performed by global scaling, with the arrays scaled to an average intensity of 500. The fold changes represent the average expression (mean average difference) levels of both duplicate target hybridisations. Genes were considered to be differentially expressed when a fold change of $\geq 2$ was detected in pair-wise comparison of both duplicates.

\section{Other statistical analysis}

Triplicate samples were analysed in all experiments unless otherwise stated and the mean values calculated. Statistical significance was evaluated by unpaired Student's $t$-test. A $P$ value of $<0.05$ was considered as significant.

\section{Cell culture}

INS-1 cells (passages 60-70) were cultured in RPMI medium (Gibco-BRL) containing $100 \mu \mathrm{g} / \mathrm{ml}$ penicillin, $100 \mu \mathrm{g} / \mathrm{ml}$ streptomycin, 10\% FCS, 2 mmol/l glutamine, $5 \mathrm{mmol} / \mathrm{l}$ glucose and $50 \mu \mathrm{mol} / \mathrm{l} \beta$-mercaptoethanol (Sigma). All cells were routinely seeded at a density of $2 \times 10^{6}$ cells $/ \mathrm{T}-75$ flask, $5 \times 10^{5}$ cells/well in a 6 -well plate, $8 \times 10^{5}$ cells/well in a 24 -well plate and $3 \times 10^{4}$ cells/well in a 96-well plate and cultured at $37^{\circ} \mathrm{C}$ under a humidified condition of $95 \%$ air and $5 \% \mathrm{CO}_{2}$.

\section{Quantitative PCR}

Total RNA was extracted from INS-1 cells using a Qiagen RNeasy kit, according to the manufacturer's directions. cDNA was synthesised from $1 \mu \mathrm{g}$ total RNA using a Taqman reverse transcription kit (PE Applied Biosystems, Foster City, CA, USA) according to the manufacturer's instructions. Taqman PCR assays for each target gene were performed in triplicate on an ABI Prism 7700 Sequence Detection system (PE Applied Biosystems). For each reaction, $1 \mathrm{ng}$ cDNA was mixed with final concentrations of $1 \times$ Taqman Universal PCR Mastermix (PE Applied Biosystems), $300 \mathrm{nmol} / \mathrm{l}$ forward and reverse primers and $200 \mathrm{nmol} / \mathrm{l}$ probe (5'-FAM, 3'-TAMRA). PGR parameters were $50{ }^{\circ} \mathrm{C}$ for $2 \mathrm{~min}, 95^{\circ} \mathrm{C}$ for $10 \mathrm{~min}$ and 40 cycles of denaturing at $95{ }^{\circ} \mathrm{C}$ for $15 \mathrm{~s}$ and annealing/extension at $60{ }^{\circ} \mathrm{C}$ for $1 \mathrm{~min}$. The primer and probe sequences are shown in Table 1.

Individual samples were measured in triplicate. Data were analysed using the standard curve method as reported in User Bulletin 21997 from Perkin-Elmer Analytical Sciences Inc. Boston, MA, USA and normalised to hypoxanthine ribosyltransferase (HPRT) expression levels.

\section{Egr-1 Western blot}

Cells were lysed with buffer containing $1 \times$ phosphatebuffered saline (PBS), 0.1\% SDS and 'complete' protease inhibitor mixture (Roche Molecular Biochemicals). Proteins were separated by electrophoresis through pre-made 4-12\% (w/v) Bis-Tris gels (Invitrogen) and transferred to polyvinylidene difluoride membranes. Membranes were incubated overnight at $4{ }^{\circ} \mathrm{C}$ in Tris-buffered saline, $0 \cdot 1 \%$ v/v Tween-20 (TBS-T) containing $5 \%$ (w/v) non-fat dried milk. Subsequently, the membranes were incubated at room temperature on a shaker with primary antibody to either Egr-1 (588) (Santa Gruz Biotechnology, Santa Gruz, CA, USA) diluted 1:1000, or $\beta$-actin (InnoGenex, San Ramon, CA, USA) diluted 1:1000 in blocking buffer for $1 \mathrm{~h}$. After three washes at room temperature, the membranes were incubated in secondary horseradish peroxidaseconjugated secondary antibody (Pierce Biotechnology Inc. Rockford, IL, USA) diluted 1:2000 in blocking buffer for $1 \mathrm{~h}$ and then washed as above. 
Immunodetection was performed with ECL detection reagents (Roche) following the manufacturer's protocol.

\section{$\left[{ }^{3} \mathrm{H}\right]$ Thymidine incorporation assay}

INS- 1 cells were plated into 96-well plates and incubated overnight. Media were carefully removed from cells and replaced with $200 \mu \mathrm{l}$ media containing the $5 \%$ FCS plus the proliferation stimulant, as described in the Results section. Recombinant human insulin-like growth factor (IGF) $(10 \mu \mathrm{mol} / \mathrm{l})($ Calbiochem from EMD Biosciences, Darmstadt, Germany) was used as a positive control for cell proliferation. Cells were incubated for $24 \mathrm{~h}$, then DNA synthesis was determined by incorporation of $\left[{ }^{3} \mathrm{H}\right]$ thymidine (Amersham) (25 $\left.\mathrm{Ci} / \mathrm{mmol}\right) \quad(1 \mu \mathrm{Ci} /$ $1 \times 10^{4}$ cells) for the final $4 \mathrm{~h}$ of the $24-\mathrm{h}$ incubation period. Media were carefully removed and cells detached with $50 \mu \mathrm{l}$ trypsin-EDTA. Cells were then harvested onto glass filters (Perkin Elmer Life and Analytical Systems, Inc., Boston, MA, USA) with a Tomtech cell harvester (also from Perkin Elmer) and the radioactivity retained on the dried filters was measured by the addition of $50 \mathrm{ml}$ scintillation liquid and counted in a TopCount NxT scintillation counter (Perkin Elmer).

\section{RNA interference}

A chemically synthesised siRNA duplex was obtained from Dharmacon Inc. (Chicago, IL, USA) annealed from single-stranded molecules of the following sequences: 5 '-agcgcuuucaauccucaag.dTdT and 5'-cuugaggauugaaa gcgcu.dTdT, representing bases 518-536 in the published rat Egr-1 mRNA sequence (Genbank Accession no. NM_012551). Vimentin siRNAs were commercially available from Dharmacon. INS-1 cells were plated in 6-well plates at a density of $5 \times 10^{5}$ cells/well and transiently transfected using transmessenger transfection reagent (Qiagen). siRNA duplexes in final concentrations from $1 \mathrm{nmol} / \mathrm{l}$ to $100 \mathrm{nmol} / \mathrm{l}$ were transfected using $32 \mu \mathrm{l}$ transmessenger transfection reagent at a ratio of $1: 8$ with the Enhancer reagent, in serum-free OPTIMEM (Invitrogen) medium, according to the manufacturer's instructions. This optimal concentration of transfection reagent gave a transfection efficiency of $60-70 \%$ in INS-1 cells as determined by using a fluorescene-labelled siRNA duplex (Dharmacon). Following a 4-h incubation with the duplexes, cells were rinsed with PBS, before extracting total RNA or protein and analysing gene expression by Taqman or Western blotting respectively, as described above.

\section{Rat insulin enzyme-linked immunosorbent assay}

Insulin content of culture medium collected from cells was determined using a rat insulin enzyme-linked immunosorbent assay (ELISA) kit (Mercodia AB,
Uppsala, Sweden). Samples were tested according to the manufacturer's $50 \mu \mathrm{l}$ sample volume protocol and insulin content was expressed in $\mu \mathrm{g} / \mathrm{l}$ by comparison of sample absorbance with a standard curve.

\section{Results}

\section{Global gene expression changes in the pre-diabetic ZDF rat islet}

To identify genes that are implicated in $\beta$-cell failure, we used Affymetrix microarrays to detect changes in gene expression in 6-week-old pre-diabetic ZDF $(f a / f a)$ rat islets, compared with the non-diabetic Zucker Fatty $(f a / f a)$ rat control. At 6 weeks old the ZDF rats are considered pre-diabetic since there is no difference in the blood glucose (ZDF: $10 \cdot 8 \pm 0 \cdot 7 \mathrm{mmol} / \mathrm{l}$, Zucker Fatty: $9 \cdot 78 \pm 0.49 \mathrm{mmol} / \mathrm{l})$, or in the fed plasma insulin levels (ZDF: $2 \cdot 37 \pm 0 \cdot 44 \mu \mathrm{g} / \mathrm{l}$, Zucker Fatty: $3 \cdot 86 \pm 0 \cdot 49 \mu \mathrm{g} / \mathrm{l}$ ) between the ZDF and Zucker Fatty rats. At 10 weeks of age, plasma glucose levels are significantly elevated in the ZDF rat $(12 \cdot 04 \pm 2 \cdot 32 \mathrm{mmol} / \mathrm{l})$ in comparison with the Zucker Fatty rat $(8 \cdot 84 \pm 0.51 \mathrm{mmol} / \mathrm{l})$. The 6-week time point was thus chosen because there is no hyperglycaemia or hyperinsulinaemia relative to Zucker Fatty rat controls (see above and Etgen \& Oldham 2000) indicating essentially normal islet function at this stage. Comparison of the ZDF and Zucker Fatty rat islets allows the specific study of genes associated with $\beta$-cell failure whilst eliminating the common genetic background responsible for insulin resistance and obesity, associated with the leptin receptor mutation. The rationale behind this was to capture early changes in gene expression which might contribute to $\beta$-cell failure, rather than changes arising as a consequence of this.

Of the 24000 genes analysed by microarray, 977 were differentially expressed in the pre-diabetic ZDF rat islets compared with the non-diabetic Zucker Fatty rat at 6 weeks of age. Genes were only considered to be differentially expressed between the ZDF and Zucker Fatty rat when a $\geq 2$-fold change was detected in replicate determinations. Under these criteria, in the ZDF rat 494 genes were up-regulated and 483 were down-regulated in comparison with the Zucker Fatty rat. As expected, no change was observed in expression of the housekeeping genes glyceraldehyde-3-phosphate dehydrogenase (GAPDH), HPRT and $\beta$-actin. The major functional groups of differentially regulated genes are displayed in Table 2. The remaining 571 differentially regulated transcripts, some of them expressed sequence tags (EST) sequences, could not be reliably annotated and thus assigned to a functional class. The full list of genes generated in this experiment can be accessed at http://www.intranet.ls.man.ac.uk/ documents/public/download.asp?item $=7375$. 
Table 2 Clustering of differentially regulated transcripts according to function. The differentially regulated transcripts were annotated and then clustered according to functional annotation. The percentage of up- and down-regulated genes within each class is displayed

\begin{tabular}{|c|c|c|c|}
\hline & $\begin{array}{l}\text { Number of differentially } \\
\text { regulated transcripts }\end{array}$ & $\begin{array}{l}\text { Percentage of transcripts } \\
\text { up-regulated in the ZDF }\end{array}$ & $\begin{array}{l}\text { Percentage of transcripts } \\
\text { down-regulated in the ZDF }\end{array}$ \\
\hline \multicolumn{4}{|l|}{ Protein functional class } \\
\hline Transcription factors & 41 & 60.9 & $39 \cdot 1$ \\
\hline Membrane proteins & 45 & $55 \cdot 6$ & $44 \cdot 4$ \\
\hline Structural and localised proteins & 27 & 25.9 & $74 \cdot 1$ \\
\hline Channels & 21 & $76 \cdot 1$ & 23.9 \\
\hline Receptors & 24 & $70 \cdot 8$ & $29 \cdot 2$ \\
\hline Enzymes & 15 & 40 & 60 \\
\hline Kinases & 23 & 43.5 & 56.5 \\
\hline Proteases & 12 & $66 \cdot 7$ & $33 \cdot 3$ \\
\hline Protease inhibitors & 9 & $66 \cdot 7$ & $33 \cdot 3$ \\
\hline Other & 167 & $48 \cdot 6$ & $51 \cdot 4$ \\
\hline Non-classified & 571 & 53 & 47 \\
\hline
\end{tabular}

This analysis has led to the identification of many genes, some being novel, which deserve further investigation in order to determine their functional role in $\beta$-cell failure. We have focussed initially on transcription factors, since changes in expression of transcription factors cause pleiotrophic effects, which will have a major impact on $\beta$-cell function (Wang et al. 2002). Totally 41 transcription factors were shown to be differentially expressed between the ZDF and Zucker Fatty rat islet. A subset was selected for further analysis on the basis of their association with apoptosis, differentiation or proliferation, since these mechanisms are likely to play a role in the survival/failure of the $\beta$-cell.

\section{Differential and tissue-specific expression of transcription factors in the rat}

To validate the microarray results, confirmation of differential expression of a subset of eight transcription factor genes was performed by quantitative RT-PCR in ZDF and Zucker Fatty rat islet RNA samples. Seven of these showed differential expression that correlated with the microarray studies (Table 3). However, the magnitude of these changes was not well matched between the two techniques in all cases. Of these genes four (rGGR19, mSin3b, PAG608 and Egr-1) were of particular interest and therefore selected for further study. rCGR19 is a p53-inducible gene, with growthsuppressive effects (Madden et al. 1996). PAG608 is a zinc finger protein, which has been shown to promote apoptosis and may also play a role in mediating the biological activities of p53 (Israeli et al. 1997). Since these genes are downstream targets of p53, it was anticipated that they might have an important role in apoptosis or growth arrest occurring in T2D islets. mSin $3 \mathrm{~b}$ is a transcriptional co-repressor known to interact with Foxk1 and Mad/Max transcription factor complexes (Ayer et al. 1995, Yang et al. 2000) which both play key

Table 3 Comparison of a set of differentially expressed transcription factors in the ZDF and Zucker Fatty rat islets measured by microarray and Taqman. Gene expression changes were analysed by Taqman RT-PCR, to confirm differential expression and allow comparison of fold changes indicated by the two techniques

\begin{tabular}{|c|c|c|c|}
\hline & $\begin{array}{l}\text { Genbank Accession } \\
\text { number }\end{array}$ & $\begin{array}{l}\text { Fold change } \\
\text { (relative to Zucker) } \\
\text { by microarray }\end{array}$ & $\begin{array}{l}\text { Fold change } \\
\text { (relative to Zucker) by Taqman } \\
\text { (significance of change) }\end{array}$ \\
\hline \multicolumn{4}{|l|}{ Gene name } \\
\hline $\mathrm{mSin} 3 b$ & AF038848 & 34.68 & $1.20 \pm 0.25\left(^{*}\right)$ \\
\hline rCGR19 & U66471 & 8.06 & $2.52 \pm 0.20\left(^{* * *}\right)$ \\
\hline Egr-1 & P08154 & $-4 \cdot 33$ & $-2 \cdot 80 \pm 0 \cdot 18\left(^{* * *}\right)$ \\
\hline PAG608 & Y13148 & -4.93 & $-4 \cdot 62 \pm 0.12\left(^{* * *}\right)$ \\
\hline GKLF & AF390546 & 3.49 & $1 \cdot 15 \pm 0.10\left(^{* *}\right)$ \\
\hline BTE & D12769 & $-3 \cdot 26$ & No change \\
\hline Ring finger binding protein & AF036255 & $7 \cdot 17$ & $1 \cdot 66 \pm 0 \cdot 24\left({ }^{* * *}\right)$ \\
\hline Fe65L2 (Amyloid beta A4 precursor binding protein) & Y13413 & 12.93 & $1.63 \pm 0.28\left(^{*}\right)$ \\
\hline
\end{tabular}

${ }^{\star} P<0.05,{ }^{* *} P<0.01,{ }^{* * *} P<0.001$ relative to Zucker. 
roles in the control of proliferation, differentiation, and apoptosis in adult progenitor cell populations (Garry et al. 2000, Luscher 2001). Thus, it is possible that $\mathrm{mSin} 3 \mathrm{~b}$ may play a role in co-ordination of cellular proliferation or differentiation of islets. Previous studies have not revealed a role for these genes in any of the constituent cell types found in the islet. A role for EGR-1 in the regulation of cell division, differentiation (Dinkel et al. 1998) and apoptosis (Pignatelli et al. 2003) has been described in many cell types. Furthermore, there is evidence that EGR-1 may play an as yet undefined role in $\beta$-cell function (Josefsen et al. 1999, Bernal-Mizrachi et al. 2001). As such, EGR-1 was selected for further analysis as it may play a similar role in the pancreatic $\beta$-cell.

Expression of these genes was analysed in a variety of tissues to determine the relative levels compared with that in the islet (Fig. 1). PAG608 expression was detected in all tissues tested, but was highest in islets, brain and lung (Fig. 1A). rCGR19 and mSin3b expressions were highest in the testis, with relatively low levels of expression in all other tissues (Fig. 1B and C respectively). Egr-1 expression was low in most tissues but showed a strikingly higher level of expression in the islet and to a much lesser extent in the brain and lung (Fig. 1D) - a surprising finding which, taken together with other studies on Egr-1 in islets and clonal $\beta$-cell lines (Susini et al. 1998, Josefsen et al. 1999, Bernal-Mizrachi et al. 2001), led us to investigate further the role of Egr-1 at the functional level in an insulinoma cell line. INS- 1 cells constitute a widely used beta-cell model and were thus selected as a tool for studying Egr-1 function.

\section{Glucose induces Egr-1 expression in insulin secreting INS- 1 cells}

Egr-1 gene expression was rapidly and reversibly induced by glucose stimulation, reaching a maximal level at $1 \mathrm{~h}$, and then returning to basal levels by $2 \mathrm{~h}$ (Fig. 2A). The kinetics of Egr-1 induction observed here are consistent with that reported in other insulin cell lines and islets (Susini et al. 1998, Josefsen et al. 1999, Bernal-Mizrachi et al. 2000). The expression level of the $80 \mathrm{kDa}$ Egr-1 protein was examined in parallel via immunoblotting (Fig. 2B). Egr-1 protein level was very low at 0 and 15 min after a shift to high glucose, but was readily detectable $30 \mathrm{~min}$ post-stimulation. Although an apparent plateau in Egr-1 protein level was observed from the 1.5 and $2 \mathrm{~h}$ time points, less intense actin expression at these points may indicate that Egr-1 protein levels were still increasing, whereas Egr-1 message levels had returned to basal levels by this time (Fig. 2B).

\section{Silencing of Egr-1 expression using RNA interference}

In order to address the role of Egr-1 in $\beta$-cell function, siRNA-mediated gene silencing was used selectively to ablate Egr-1 expression in INS-1 cells. After optimisation experiments, an siRNA duplex directed against the Egr-1 gene was transfected into INS-1 cells at three concentrations, for 24, 48 or 72 h (Fig. 3). In comparison with a scrambled non-silencing siRNA, maximum reduction of Egr-1 mRNA expression (approximately $80 \% ; P<0.05)$ was achieved with $100 \mathrm{nmol} / 1$ siRNA at $24 \mathrm{~h}$ post-transfection (Fig. 3A). After $72 \mathrm{~h}$, no significant reduction in gene expression was observed.

Egr-1 protein level was analysed in siRNA-transfected cells by immunoblotting with anti-Egr-1 antibody, to assess whether or not reduction of mRNA content also resulted in reduction of translation. At $100 \mathrm{nmol} / \mathrm{l}$ siRNA, Egr-1 protein level was significantly reduced at $24 \mathrm{~h}$ (Fig. 3B), corresponding to maximal reduction in mRNA synthesis. siRNA at 1 and $10 \mathrm{nmol} / \mathrm{l}$ did not seem to affect protein levels, even though inhibition of mRNA synthesis was evident. After 48 h, Egr-1 protein levels appeared to have increased again in the presence of $100 \mathrm{nmol} / \mathrm{l}$ siRNA, although a slight reduction in level does still seem apparent in comparison with the scrambled control (Fig. 3B). Hence, it is apparent that this Egr-1 siRNA is maximally effective at $24 \mathrm{~h}$ post-transfection.

\section{Egr-1 siRNA treatment abolishes glucose-induced Egr-1 induction}

To determine whether siRNA-mediated gene silencing could block transient glucose-stimulated Egr-1 gene expression, we transfected INS-1 cells with Egr-1-specific siRNAs $(100 \mathrm{nmol} / \mathrm{l})$ for $24 \mathrm{~h}$ prior to glucose treatment. In the cells transfected with Egr-1 siRNAs (Fig. 4A), there was an initial rapid induction in Egr-1 expression up to $15 \mathrm{~min}$ following glucose treatment. However, in comparison with control cells, there was a dramatic reduction in the peak level of Egr-1 expression induction seen following glucose treatment. These findings illustrate that in addition to reducing existing mRNA levels, siRNA treatment is very efficient in reducing glucose-induced Egr-1 gene expression levels.

\section{Egr-1 gene silencing has no effect on insulin secretion}

Previous studies have shown that induction of Egr-1 expression by glucose is closely associated with insulin secretion (Josefsen et al. 1999, Bernal-Mizrachi et al. 2000). In order to explore the possibility that Egr-1 plays a role in insulin secretion, insulin secretion was monitored from cells transfected with Egr-1 siRNA. Medium was removed from siRNA-transfected cells, which had been stimulated with $20 \mathrm{mmol} / \mathrm{l}$ glucose over a 3-h time course, and assessed for insulin content using ELISA. The gradual cumulative increase in insulin secretion over this time period was not significantly 

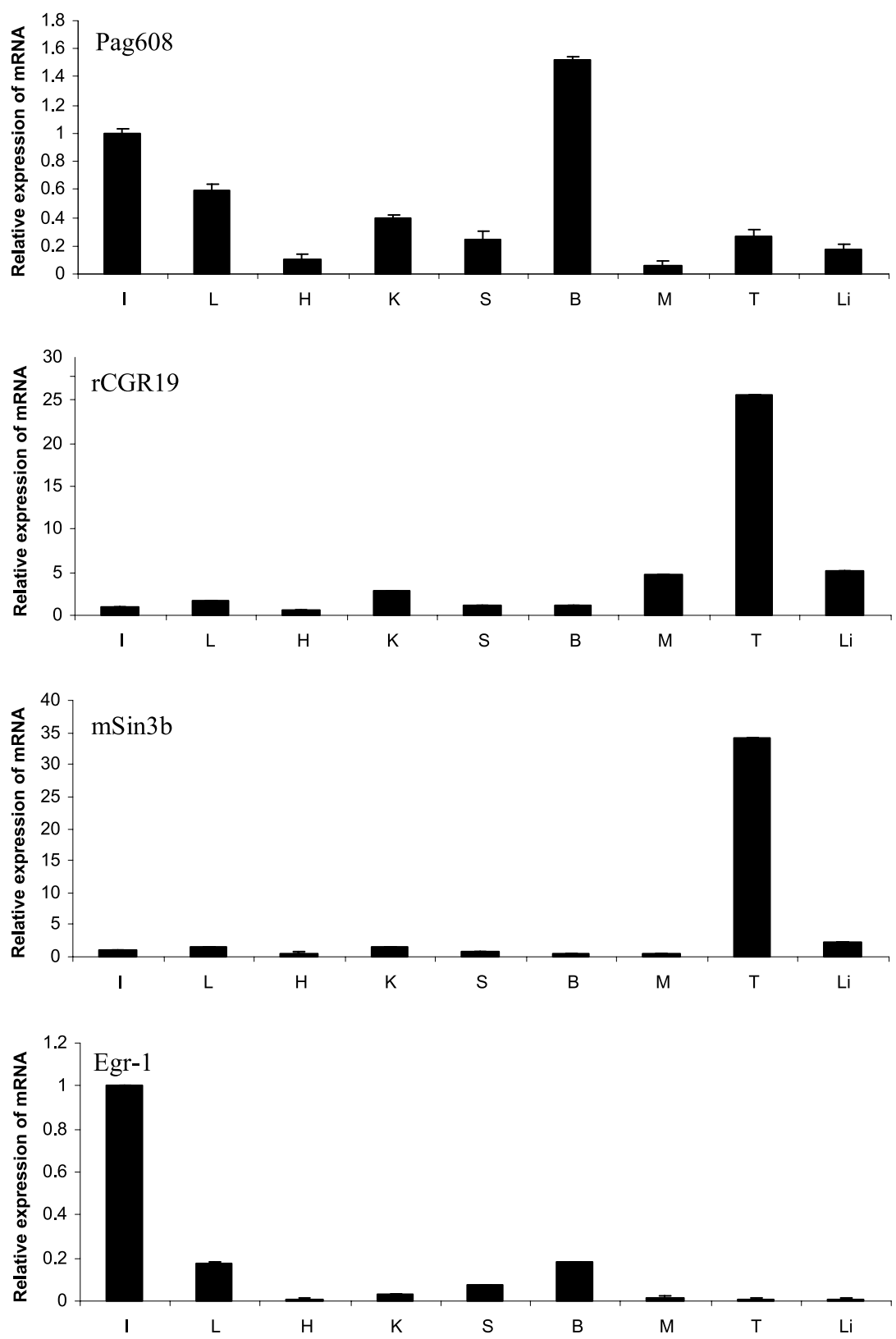

Figure 1 Tissue expression profiling of transcription factor genes in the pancreatic islet. Profiling was conducted on a subset of the transcription factors identified as being differentially expressed between ZDF and Zucker. Expression in normal tissues derived from male Sprague-Dawley rats (Clontech, Multiple Tissue cDNA panel) was assessed using Taqman quantitative RT-PCR and normalised using the HPRT housekeeping gene as an internal control. Tissues are pooled from $\geq 200$ rats and expression was measured in triplicate. Profiles for the following genes are shown: (A) PAG608, (B) rCGR19, (C) mSin3b and (D) Egr-1. For each gene the following tissues were analysed: I, islets; L, lung; $\mathrm{H}$, heart; K, kidney; S, spleen; $\mathrm{B}$, brain; M, skeletal muscle; T, testis; and L, liver. Results are shown as means \pm S.E.M. and made relative to expression of mRNA in the islet. 
(A)

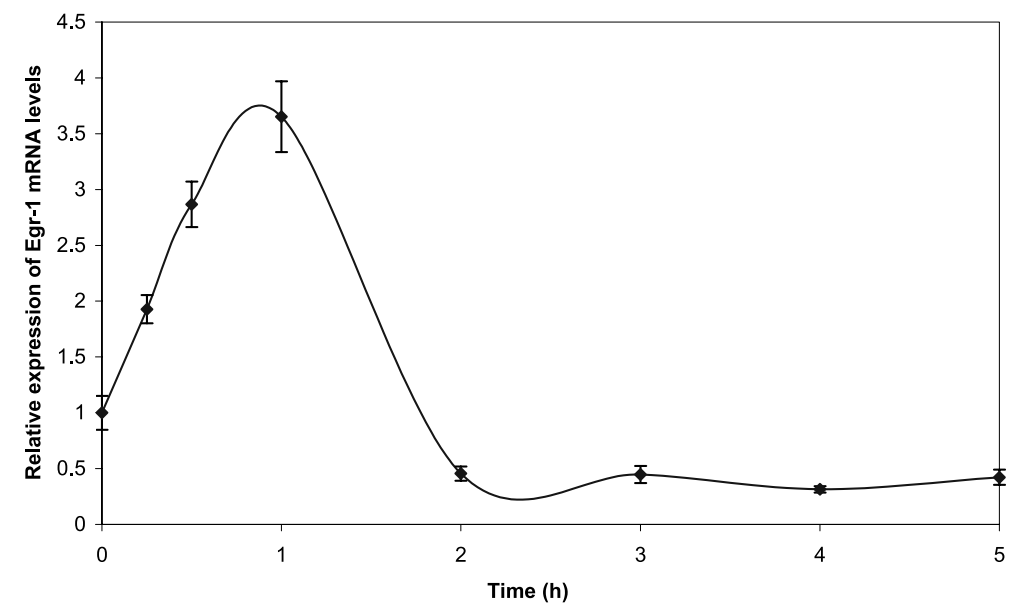

(B)

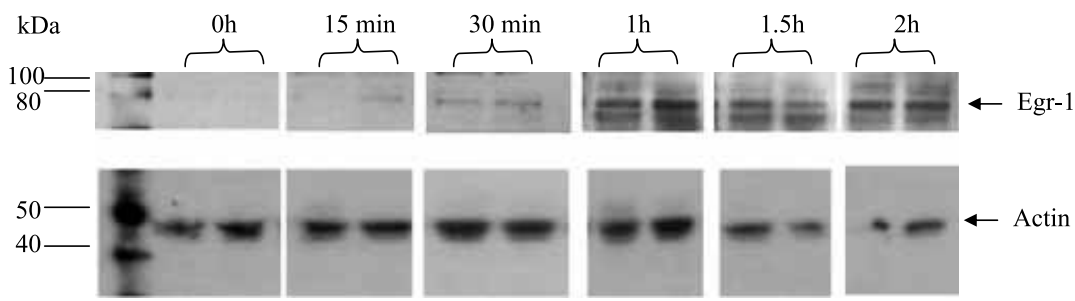

Figure 2 Egr-1 gene transcription and translation is rapidly induced by glucose treatment. INS-1 cells were glucose-deprived by growth in normal medium containing $1 \mathrm{mmol} / \mathrm{l}$ glucose for $1 \mathrm{~h}$, then exposed to high glucose $(25 \mathrm{mmol} / \mathrm{l})$. (A) Induction of Egr-1 mRNA synthesis by glucose. RNA was extracted from cells and analysed for Egr-1 mRNA levels by Taqman RT-PCR. Expression was normalised to the housekeeping gene HPRT. Results are means \pm S.E.M. from 3 independent observations. (B) Induction of Egr-1 protein synthesis by glucose. Total protein was extracted and resolved by $4-12 \%$ SDS-PAGE as described in the Materials and methods section. Egr-1 ( $80 \mathrm{kDa}$ ) expression was assessed by immunoblotting with an anti-Egr-1 antibody. Equal loading of total protein was monitored by immunoblotting with an anti-actin $(43 \mathrm{kDa})$ antibody. Each experiment was performed in duplicate.

affected by the presence of Egr-1 siRNAs compared with the control cells (Fig. 4B). Thus it appears that silencing of Egr-1 expression does not affect total insulin secretion over this time period.

\section{Silencing of Egr-1 inhibits $\beta$-cell proliferation}

Several studies have suggested that Egr-1 plays a role in the regulation of cell differentiation and proliferation (Perez-Castillo et al. 1993, Krishnaraju et al. 1998, Bernal-Mizrachi et al. 2000, Pignatelli et al. 2003). Therefore, to determine whether Egr-1 plays a role in $\beta$-cell proliferation, the proliferation rate of Egr-1 siRNA-transfected INS-1 cells in response to glucose treatment was monitored. Cells were transfected with Egr-1-specific siRNAs for $24 \mathrm{~h}$ in the presence of
$5 \mathrm{mmol} / \mathrm{l}$ glucose. The media were removed and replaced with normal growth media containing either 5 or $20 \mathrm{mmol} / \mathrm{l}$ glucose in the presence of $5 \%$ serum. As a negative control, transfection of siRNAs against a non-related gene, vimentin, was used to show the specific effects of silencing Egr-1 expression on proliferation. siRNAs directed against the vimentin gene had previously been shown in our hands to reduce GAPDH expression by $60 \%$ (data not shown). IGF-I $(10 \mu \mathrm{mol} / \mathrm{l})$ plus $5 \%$ serum was used as a positive control for $\beta$-cell proliferation. Incorporation of $\left[{ }^{3} \mathrm{H}\right]$ thymidine over the final $4 \mathrm{~h}$ of a 24-h incubation period was used to measure cell proliferation. IGF-I caused a $3 \cdot 2$-fold increase in cell proliferation. Transfection with Egr-1 siRNA significantly $(P<0 \cdot 001)$ decreased cell proliferation in the presence of both $5 \mathrm{mmol} / \mathrm{l}$ and $20 \mathrm{mmol} / \mathrm{l}$ glucose (Fig. 5) in comparison with the 
(A)

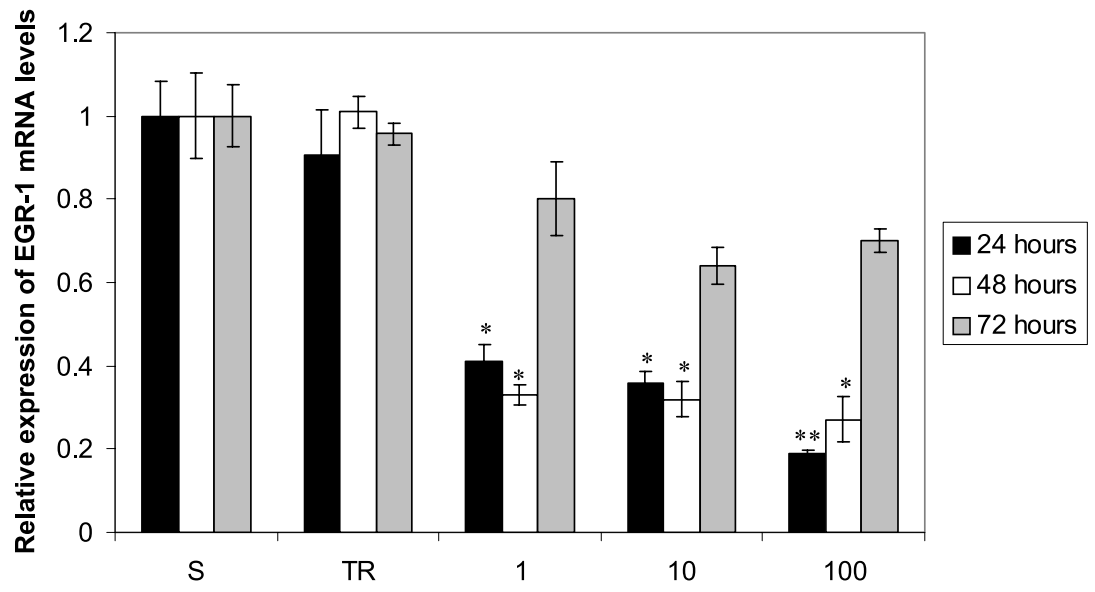

(B)

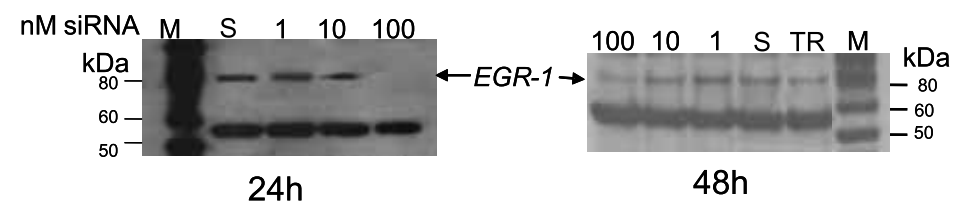

Figure 3 Silencing of Egr-1 gene expression by Egr-1 siRNA duplexes. (A) Concentration and time-dependent siRNA-mediated silencing of Egr-1 mRNA synthesis. A chemically synthesised Egr-1 siRNA duplex was transfected into INS-1 cells at varying concentrations. The effect of the duplex on Egr-1 gene expression was determined at 24, 48 and $72 \mathrm{~h}$ (black, white and grey bars respectively) by Taqman RT-PCR. Results are means \pm S.E.M. made relative to the scrambled (S) non-silencing control from 3 independent experiments. ${ }^{* *} P<0.01,{ }^{*} P<0.05$ relative to the scrambled control. TR, transfection reagent alone. (B) Expression of Egr-1 protein in siRNA-treated INS-1 cells. INS-1 cells were treated with siRNA for 24 and $48 \mathrm{~h}$. Total protein was extracted and resolved by $4-12 \%$ SDS-polyacrylamide gel electrophoresis as described. Egr-1 expression was assessed by immunoblotting with an anti-Egr-1 antibody. S, scrambled non-silencing siRNA; TR, transfection reagent alone; M, marker. Equal loading of total protein was monitored by Coomassie brilliant blue staining for all samples (data not shown).

vimentin and transfection reagent alone controls. These data show that inhibition of Egr-1 expression causes a decrease in proliferation of INS-1 cells in a glucoseindependent manner, but it is not sufficient to completely inhibit an increase in proliferation caused by glucose stimulation.

\section{Discussion}

To identify genes that are implicated in $\beta$-cell failure, we used Affymetrix microarrays to detect changes in gene expression. Comparison of the ZDF and Zucker Fatty rat islets of 6-week-old animals allows the specific study of genes associated with $\beta$-cell failure whilst eliminating the common genetic background responsible for insulin resistance and obesity, making it more likely that changes in gene expression which trigger predispose-to- $\beta$-cell failure would be observed. At this age, alterations in gene regu- lation are unlikely to have arisen as a result of changes in measurable $\beta$-cell function. We identified 977 differentially regulated genes in 6-week-old pre-diabetic ZDF $(f a / f a)$ rat islets, compared with the non-diabetic Zucker Fatty $(f a / f a)$ rat control. It must be remembered that since islets are composed of different cell types, this list will include genes expressed in non- $\beta$ cells. However, $\beta$-cells do represent the majority of cell types in a normal islet.

Transcripts of a number of important $\beta$-cell genes previously shown to be altered in diabetes, including PDX-1, insulin, glucokinase and GLUT2 are represented on the RG-U34 array set, but we detected no changes in their expression levels. It is possible that they are not implicated in $\beta$-cell failure at this pre-diabetic stage or that expression levels of these genes are altered later in the progression of $\beta$-cell failure, perhaps as a result of, or the cause of, changes in $\beta$-cell mass. The lack of change in PDX-1 expression at 6 weeks agrees with other studies (Tokuyama et al. 1995). It is also 


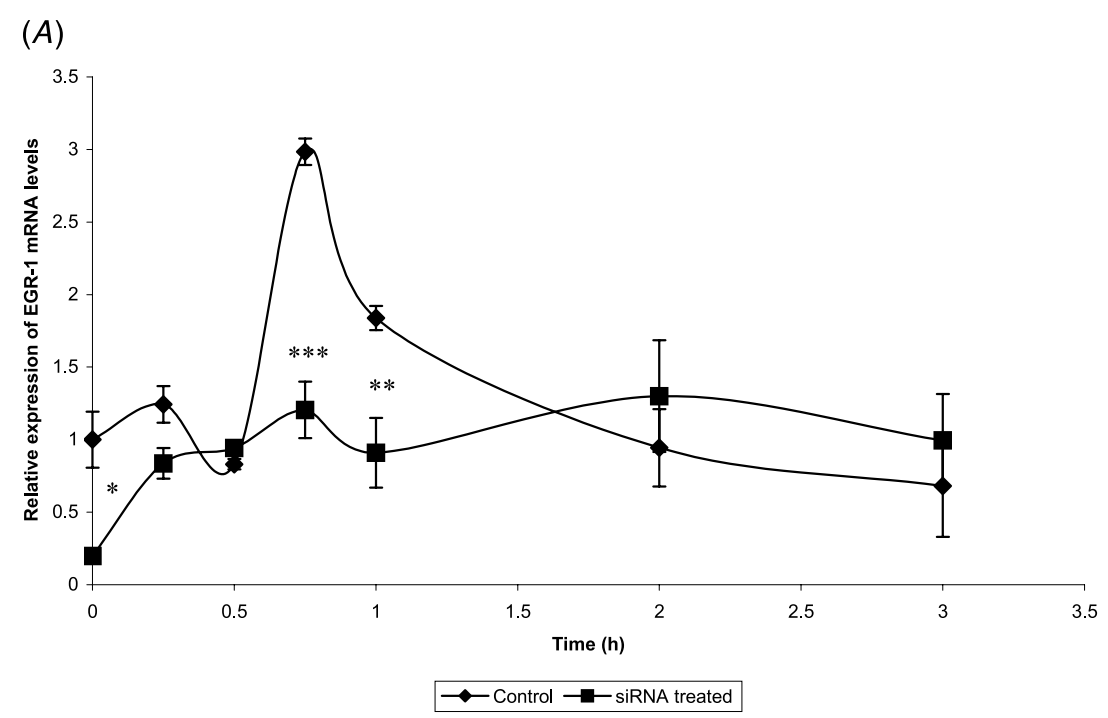

(B)

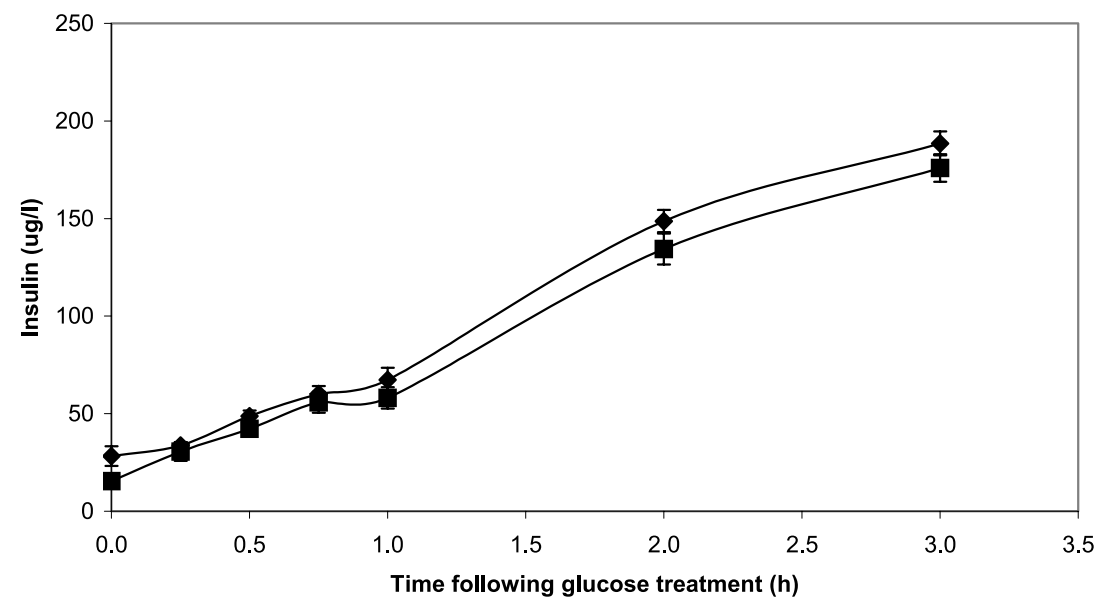

Plus siRNA -Minus siRNA

Figure 4 Induction of Egr-1 gene expression by glucose is blocked by Egr-1 siRNA treatment in INS-1 cells but has no effect on total insulin secretion. INS-1 cells were transfected with a chemically synthesised Egr-1 duplex $(100 \mathrm{nmol} / \mathrm{l})$ for $24 \mathrm{~h}$ in $5 \mathrm{mmol} / \mathrm{l}$ glucose. Cells were glucose-deprived by growth in normal medium containing $1 \mathrm{mmol} / \mathrm{l}$ glucose for $1 \mathrm{~h}$, then stimulated with $25 \mathrm{mmol} / \mathrm{l}$ glucose over a period of $3 \mathrm{~h}$. Transfection reagent alone-treated cells were included as a control. (A) Total RNA was extracted and analysed for Egr-1 expression in triplicate using Taqman RT-PCR. Results are means \pm S.E.M. from 3 independent experiments and were made relative to the transfection reagent alone control result at $0 \mathrm{~h}$. ${ }^{\star \star *} P_{<000}$, ${ }^{* *} P<0.01$, ${ }^{*} P<0.05$ relative to transfection reagent alone control. (B) Medium was removed and assayed for insulin content using insulin ELISA. Each experiment was performed in duplicate and insulin concentration was assessed in duplicate. Results are means \pm S.E.M. from 3 independent experiments.

noteworthy that this screen indicated there was relative under-expression of the glucagon-like peptide-1 (GLP-1) receptor and Foxa2 genes in the ZDF rat and altered expression patterns for several genes involved in the regulation of lipid metabolism. These changes in gene expression would be likely to have profound effects on $\beta$-cell function, at least later in the disease progression. Indeed it has been shown that Foxa2 regulates a set of transcription factors which are vital for $\beta$-cell function (Lee et al. 2002). Further functional studies would be 


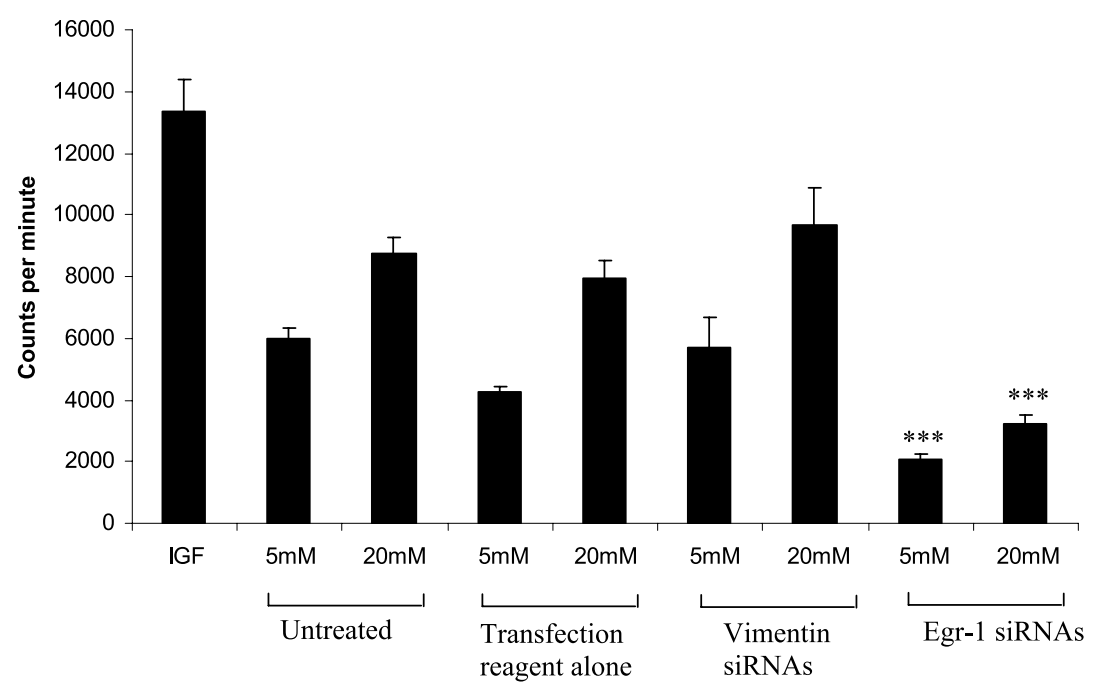

Figure 5 Proliferation of INS-1 $\beta$-cells is inhibited by siRNA-mediated Egr- 1 gene silencing. INS-1 cells $\left(3 \times 10^{4}\right)$ were transfected with Egr-1 siRNAs $(100 \mathrm{nmol} / \mathrm{I})$ for $24 \mathrm{~h}$, then treated with either 5 or $20 \mathrm{mmol} / \mathrm{l}$ glucose for a further $24 \mathrm{~h}$. Silencing of an unrelated gene, vimentin, using vimentin-specific siRNAs was used as a negative control. IGF $(10 \mu \mathrm{mol} / \mathrm{l})$ was used as a positive control for cell proliferation. Proliferation was assessed by measuring $\left[{ }^{3} \mathrm{H}\right]$ thymidine incorporation over the last $4 \mathrm{~h}$ of the final incubation. Results are means \pm S.E.M. from 3 independent experiments. ${ }^{* \star} P<0.001$ relative to corresponding transfection reagent alone control.

required to confirm all of these observations and determine their significance.

A subset of the differentially regulated transcription factor genes were further analysed by Taqman RT-PCR to confirm differential expression. The magnitude of changes as measured by the two methods was quite different for some genes. This agrees with other observations (Nadler et al. 2000, Webb et al. 2001) and might be attributed to the different sensitivity and methodologies of the two techniques or the quality of those particular probe sets/primer pairs. It is likely that the accuracy of the fold changes indicated by the microarrays would be improved by increasing the number of replicate targets synthesised and hybridised to arrays. However, the RT-PCR did confirm differential expression in the same orientation as revealed by microarray analysis, giving us confidence in our results.

We chose to focus our subsequent studies on the role of Egr-1 in the $\beta$-cell for three reasons. First, Egr-1 has been implicated in the regulation of differentiation, proliferation and apoptosis in neuroendocrine and lymphoid cells (Perez-Castillo et al. 1993, Dinkel et al. 1998, Thiel \& Cibelli 2002, Pignatelli et al. 2003); secondly, Egr-1 expression is regulated by glucose in $\beta$-cells but not in other cells (Josefsen et al. 1999, Bernal-Mizrachi et al. 2001) and finally because we have shown here that Egr-1 expression is high in the islet. We therefore hypothesised that Egr-1 might play an important role in $\beta$-cell function and we set out to explore this by studying the effect of Egr-1 gene silencing in the INS-1 insulinoma cell line. Ablation of Egr-1 gene induction by glucose had no effect on cumulative insulin secretion over a 3-h time interval, indicating that despite the very closely related signal transduction pathways which trigger insulin secretion and Egr-1 gene induction, no immediate functional relationship exists between the two events. However, a more appropriate study would be to measure actual glucose-induced insulin secretion by comparing stimulated insulin levels with basal secretion. It also remains to be determined whether Egr-1 and/or other nutrient-induced immediate-early genes (Pignatelli et al. 1999) contribute to the regulatory pathways of the key $\beta$-cell-specific nutrient-regulated genes such as insulin or glucokinase.

This study has, however, revealed a regulatory role for Egr-1 in $\beta$-cell proliferation that may be significant in the context of its decreased expression in ZDF rat islets. It has been suggested that Egr-1 may play a role in adaptation of $\beta$-cells to increased insulin resistance and nutrient levels in the normal situation (Josefsen et al. 1999) and our data would tend to support this view. Furthermore, recent studies have highlighted two important findings which have a direct bearing on our results - that $\beta$-cell proliferation is more prominent than neogenesis in maintaining adult $\beta$-cell mass (Dor et al. 2004) and that there is a direct genetic link between proliferative capacity and diabetogenesis (Brun et al. 2004). Although Egr-1 gene silencing did not completely 
abolish glucose-stimulated proliferation, it generally reduced proliferation rates such that the proliferation rate of INS-1 cells in high glucose was comparable with control cells in low glucose. Egr-1 expression can be induced by many insulin secretagogues (Susini et al. 1998, Josefsen et al. 1999), so it may be a common point at which any general nutrient excess which stimulates insulin secretion could be integrated to provide a proportionate proliferative signal in the face of nutrient overload. The study of Finegood et al. (2001) suggests that impaired glucose-induced stimulation of $\beta$-cell proliferation may contribute to the development of hyperglycaemia in the ZDF rat. Our data suggest that the Egr-1 pathway would be compromised in the ZDF rat islet and may, along with other factors, contribute to the deficit in $\beta$-cell compensation seen in animal models of T2D.

Interestingly, the Egr-1 null mouse has no diabetic phenotype and appears normal (Lee et al. 1995) with the exception of infertility in homozygous null females (Lee et al. 1996). However, as suggested above, the physiological roles of Egr-1 in the islet might only become manifest in response to an environmental challenge such as nutrient excess and/or insulin resistance. Breeding of the Egr-1 null mutation onto an obese, insulin-resistant background and/or feeding a diabetogenic diet may thus reveal a role for Egr-1 in $\beta$-cell compensation to nutrient excess and insulin resistance.

\section{Acknowledgements}

This work was supported by the BBSRC and AstraZeneca Pharmaceuticals, UK. We would like to thank Carolyn Spraggon, AstraZeneca, for technical help with the microarray work. Also, we are very grateful to Laraine Ellershaw for technical help with the animals used in this study and to Professor Noel Morgan, Peninsula Medical School, Plymouth, UK and Dr Steve Thomas, Keele University, UK.

\section{Funding}

This research was funded by AstraZeneca, Alderley Park, Cheshire, UK. There is no conflict of interest that would prejudice its impartiality.

\section{References}

Ayer DE, Lawrence QA \& Eisenman RN 1995 Mad-Max transcriptional repression is mediated by ternary complex formation with mammalian homologs of yeast repressor Sin3. Cell $80767-776$.
Bernal-Mizrachi E, Wice B, Inoue H, \& Permutt MA 2000 Activation of serum response factor in the depolarization induction of Egr-1 transcription in pancreatic islet beta-cells. Journal of Biological Chemistry 275 25681-25689.

Bernal-Mizrachi E, Wen W, Srinivasan S, Klenk A, Cohen D \& Permutt MA. 2001 Activation of Elk-1, an Ets transcription factor, by glucose and EGF treatment of insulinoma cells. American fournal of Physiology, Endocrinology and Metabolism 281 E1286-E1299.

Brun T, Franklin I, St-Onge L, Biason-Lauber A, Schoenle EJ, Wollheim CB \& Gauthier BR 2004 The diabetes-linked transcription factor PAX4 promotes beta-cell proliferation and survival in rat and human islets. Fournal of Cell Biology $\mathbf{1 6 7}$ $1123-1135$.

Der SD, Zhou A, Williams BR \& Silverman RH 1998 Identification of genes differentially regulated by interferon alpha, beta, or gamma using oligonucleotide arrays. PNAS 95 15623-15628.

Dinkel A, Warnatz K, Ledermann B, Rolink A, Zipfel PF, Burki K \& Eibel H 1998 The transcription factor early growth response 1 (Egr-1) advances differentiation of pre-B and immature B cells. Fournal of Experimental Medicine 188 2215-2224.

Dor Y, Brown J, Martinez OI \& Melton DA 2004 Adult pancreatic beta-cells are formed by self-duplication rather than stem-cell differentiation. Nature 429 41-46.

Etgen GJ \& Oldham BA 2000 Profiling of Zucker diabetic fatty rats in their progression to the overt diabetic state. Metabolism: Clinical and Experimental $49684-688$.

Finegood DT, McArthur MD, Kojwang D, Thomas MJ, Topp BG, Leonard T \& Buckingham RE 2001 Beta-cell mass dynamics in Zucker diabetic fatty rats. Rosiglitazone prevents the rise in net cell death. Diabetes 50 1021-1029.

Garry DJ, Meeson A, Elterman J, Zhao Y, Yang P, Bassel-Duby R \& Williams RS 2000 Myogenic stem cell function is impaired in mice lacking the forkhead/winged helix protein MNF. PNAS $\mathbf{9 7}$ $5416-5421$

Griffen SC, Wang J \& German MS 2001 A genetic defect in beta-cell gene expression segregates independently from the fa locus in the ZDF rat. Diabetes $\mathbf{5 0} 63-68$.

Israeli D, Tessler E, Haupt Y, Elkeles A, Wilder S, Amson R, Telerman A \& Oren M 1997 A novel p53-inducible gene, PAG608, encodes a nuclear zinc finger protein whose overexpression promotes apoptosis. EMBO Journal $164384-4392$.

Jonas JC, Sharma A, Hasenkamp W, Ilkova H, Patane G, Laybutt R, Bonner-Weir S \& Weir GC 1999 Chronic hyperglycemia triggers loss of pancreatic beta cell differentiation in an animal model of diabetes. Fournal of Biological Chemistry 274 14112-14121.

Josefsen K, Sorensen LR, Buschard K \& Birkenbach M 1999 Glucose induces early growth response gene (Egr-1) expression in pancreatic beta cells. Diabetologia 42 195-203.

Krishnaraju K, Hoffman B \& Liebermann DA 1998 The zinc finger transcription factor Egr-1 activates macrophage differentiation in M1 myeloblastic leukemia cells. Blood 92 1957-1966.

Lee Y, Hirose H, Ohneda M, Johnson JH, McGarry JD \& Unger RH 1994 Beta-cell lipotoxicity in the pathogenesis of non-insulin-dependent diabetes mellitus of obese rats: impairment in adipocyte-beta-cell relationships. PNAS 91 10878-10882.

Lee SL, Tourtellotte LC, Wesselschmidt RL \& Milbrandt J 1995 Growth and differentiation proceeds normally in cells deficient in the immediate early gene NGFI-A. Fournal of Biological Chemistry 270 9971-9977.

Lee SL, Sadovsky Y, Swirnoff AH, Polish JA, Goda P, Gavrilina G \& Milbrandt J 1996 Luteinizing hormone deficiency and female infertility in mice lacking the transcription factor NGFI-A (Egr-1). Science 273 1219-1221.

Lee CS, Sund NJ, Vatamaniuk MZ, Matschinsky FM, Stoffers DA \& Kaestner KH 2002 Foxa2 controls Pdxl gene expression in pancreatic beta-cells in vivo. Diabetes 51 2546-2551.

Luscher B 2001 Function and regulation of the transcription factors of the Myc/Max/Mad network. Gene 277 1-14. 
Madden SL, Galella EA, Riley D, Bertelsen AH \& Beaudry GA 1996 Induction of cell growth regulatory genes by p53. Cancer Research 56 5384-5390.

Montague W \& Taylor KW 1968 Pentitols and insulin release by isolated rat islets of Langerhans. Biochemical Fournal 109 333-339.

Nadler ST, Stoehr JP, Schueler KL, Tanimoto G, Yandell BS \& Attie AD 2000 The expression of adipogenic genes is decreased in obesity and diabetes mellitus. PNAS 97 11371-11376.

Perez-Castillo A, Pipaon C, Garcia I \& Alemany S 1993 NGFI-A gene expression is necessary for $\mathrm{T}$ lymphocyte proliferation. fournal of Biological Chemistry 268 19445-19450.

Phillips MS, Liu Q Hammond HA, Dugan V, Hey PJ, Caskey CJ \& Hess JF 1996 Leptin receptor missense mutation in the fatty Zucker rat. Nature Genetics 13 18-19.

Pick A, Clark J, Kubstrup C, Levisetti M, Pugh W, Bonner-Weir S \& Polonsky KS. 1998 Role of apoptosis in failure of beta-cell mass compensation for insulin resistance and beta-cell defects in the male Zucker diabetic fatty rat. Diabetes 47 358-364.

Pignatelli M, Cortes-Canteli M, Santos A \& Perez-Castillo A 1999 Involvement of the NGFI-A gene in the differentiation of neuroblastoma cells. FEBS Letters 461 37-42.

Pignatelli M, Luna-Medina R, Perez-Rendon A, Santos A \& Perez-Castillo A 2003 The transcription factor early growth response factor-1 (EGR-1) promotes apoptosis of neuroblastoma cells. Biochemical Fournal 373 739-746.

Polonsky KS, Sturis J \& Bell GI 1996 Seminars in medicine of the Beth Israel Hospital, Boston. Non-insulin-dependent diabetes mellitus - a genetically programmed failure of the beta cell to compensate for insulin resistance. New England Journal of Medicine 334 777-783.

Prentki M, Joly E, El-Assaad W \& Roduit R 2002 Malonyl-CoA signaling, lipid partitioning, and glucolipotoxicity: role in beta-cell adaptation and failure in the etiology of diabetes. Diabetes $\mathbf{5 1}$ S405-S413.

Seufert J, Weir GC \& Habener JF 1998 Differential expression of the insulin gene transcriptional repressor CCAAT/enhancerbinding protein beta and transactivator islet duodenum homeobox-1 in rat pancreatic beta cells during the development of diabetes mellitus. Fournal of Clinical Investigation 101 2528-2539.

Susini S, Roche E, Prentki M \& Schlegel W 1998 Glucose and glucoincretin peptides synergize to induce c-fos, c-jun, junB, zif-268, and nur-77 gene expression in pancreatic beta (INS-1) cells. Fournal of the Federation of American Societies for Experimental Biology 12 1173-1182.

Tamemoto H, Kadowaki T, Yamauchi T, Terauchi Y, Kaburagi Y \& Kadowaki T 1994 Insulin resistance and growth retardation in mice lacking insulin receptor substrate-1. Nature 372 182-186.

Terauchi Y, Iwamoto K, Tamemoto H, Komeda K, Ishii C, Kanazawa Y, Asanuma N, Aizawa T, Akanuma Y, Yasuda K, Kodama T, Tobe K, Yazaki Y \& Kadowaki T 1997 Development of non-insulin-dependent diabetes mellitus in the double knockout mice with disruption of insulin receptor substrate- 1 and beta cell glucokinase genes. Genetic reconstitution of diabetes as a polygenic disease. Fournal of Clinical Investigation 99 861-866.

Thiel G \& Cibelli G 2002 Regulation of life and death by the zinc finger transcription factor Egr-1. Fournal of Cellular Physiology 193 287-292.

Tokuyama Y, Sturis J, DePaoli AM, Takeda J, Stoffel M, Tang J, Sun X, Polonsky KS \& Bell GI 1995 Evolution of beta-cell dysfunction in the male Zucker diabetic fatty rat. Diabetes $\mathbf{4 4}$ $1447-1457$.

Wang H, Hagenfeldt-Johansson K, Otten LA, Gauthier BR, Herrera PL \& Wollheim CB 2002 Experimental models of transcription factor-associated maturity-onset diabetes of the young. Diabetes $\mathbf{5 1}$ S333-S42.

Webb GC, Akbar MS, Zhao C \& Steiner DF 2001 Expression profiling of pancreatic beta-cells: glucose regulation of secretory and metabolic pathway genes. Diabetes 50 S135-S136.

Weir GC, Laybutt DR, Kaneto H, Bonner-Weir S \& Sharma A 2001 Beta-cell adaptation and decompensation during the progression of diabetes. Diabetes $\mathbf{5 0}$ S154-S159.

Yang Q Kong Y, Rothermel B, Garry DJ, Bassel-Duby R \& Williams RS 2000 The winged-helix/forkhead protein myocyte nuclear factor beta (MNF-beta) forms a co-repressor complex with mammalian sin3B. Biochemical fournal 345 335-343.

Received 1 April 2005

Accepted 20 April 2005

Made available online as an

Accepted Preprint 10 May 2005 